\section{AZ IDŐSÖDÉS FOGALMÁNAK EGY LEHETSÉGES \\ ÁTDEFINIÁLÁSA ÉS ENNEK IMPLIKÁCIÓ| \\ AZ ÉLETTARTAM FOKOZATOS NÖVEKEDÉSÉBŐL ADÓDÓ \\ KIHÍVÁSOK A MAGYAR TB NYUGDÍJ ALRENDSZERÉBEN \\ - LEHETSÉGES VÁLASZOK}

Banyár József(egyetemi docens, Budapesti Corvinus Egyetem), jozsef.banyar@uni-corvinus.hu

\section{ÖSSZEFOGLALÓ}

A társadalombiztosítást (különösen a folyó finanszírozású nyugdíjrendszert) Magyarországon (de az összes fejlett országban is) erősen sújtja az idősödés. Úgy tűnik, hogy ennek a folyamatnak két forrása van: az egyre növekvő várható élettartam és az alacsony teljes termékenységi mutató (total fertility ratio = TFR). Ebben az elemzésben megpróbálom bemutatni, hogy csak a második az igazi probléma, a növekvő várható élettartamot könnyen kezelhetjük nyugdíjkorhatár-indexálással, aminek a módszerére reformjavaslatot is teszek. $\mathrm{Az}$ alacsony TFR kezelésére javasolt megoldásomat itt csak jelzem, illetve megmutatom, mely írásaimban dolgoztam ki részletesebben.

\section{SUMMARY}

The social security system (and especially the PAYG pension) is hit by ageing in Hungary (but also in all developed countries). It seems, that there are two sources of this process: enhancing longevity and low total fertility ratio (TFR). In this analysis I try to demonstrate, that only the second is the real problem, longevity can be handled by simple age limit indexation. I put forward a proposal for the reform of its methodology. I only indicate my solution for the handling of low TFR here and indicate in which of my previous publications I have developed it in greater detail.

Kulcsszavak: idősödés, élettartam-növekedés, TFR, nyugdíj,

Key words: ageing, longevity, TFR, pension

JEL: B22, D30, H55

DOI: $10.18530 /$ BK.2020.3-4.28

http://dx.doi.org/10.18530/BK.2020.3-4.28

\section{BEVEZETÉS}

A Magyarországon és a legtöbb fejlett országban legfontosabb nyugdíj alrendszer - az államilag szervezett, folyó finanszírozású nyugdíjrendszer - előtt álló egyik legfontosabb kihívás az idősödés. Ezt két okra szokták bontani:

1. az egyre növekvő élettartamra, és

2. az alacsony (sőt egyre csökkenő) teljes termékenységi mutató (total fertility ratio=TFR) hatására.

E két tényező okozza azt, hogy az idősek aránya - értve ez alatt egy rögzített kor feletti népesség arányát - egyre nagyobb lesz a népességen belül.

Az alábbiakban amellett érvelek, hogy indokolatlan az egy rögzített kor felettieket idősnek tekinteni, mert az élettartam növekedésével nő az egészségben eltöltött idő is, így az „idős” fogalmát relativizálni kell, és folyamatosan ki kell igazítani, mégpedig a nyugdíjkorhatár folyamatos indexálása révén. Ennek bevezetésével - aminek lehetséges módszereit megvizsgálom, és javaslatot is teszek valamelyik alkalmazására - az első idősödési tényezőt hatástalanítani lehet, és el lehet érni, hogy a nyugdíjrendszer problémáit kizárólag a 2. tényező, az alacsony TFR okozza. Természetesen ez a nagyobbik probléma, ezzel azonban itt csak érintőlegesen foglalkozom, idézem azokat a tanulmányaimat, ahol a problémát és annak lehetséges megoldásait részletesen kifejtem.

Mint tudjuk, a várható hátralévő élettartam már évszázadok óta folyamatosan nő szerte a világon, de az utóbbi évtizedekben ez a növekedés felgyorsult, látványossá vált - ahogy az 1 . ábra is mutatja -, és egyelöre nem is látjuk a folyamat végét. ${ }^{1}$

1. ábra: Uniszex születésnél várható élettartam

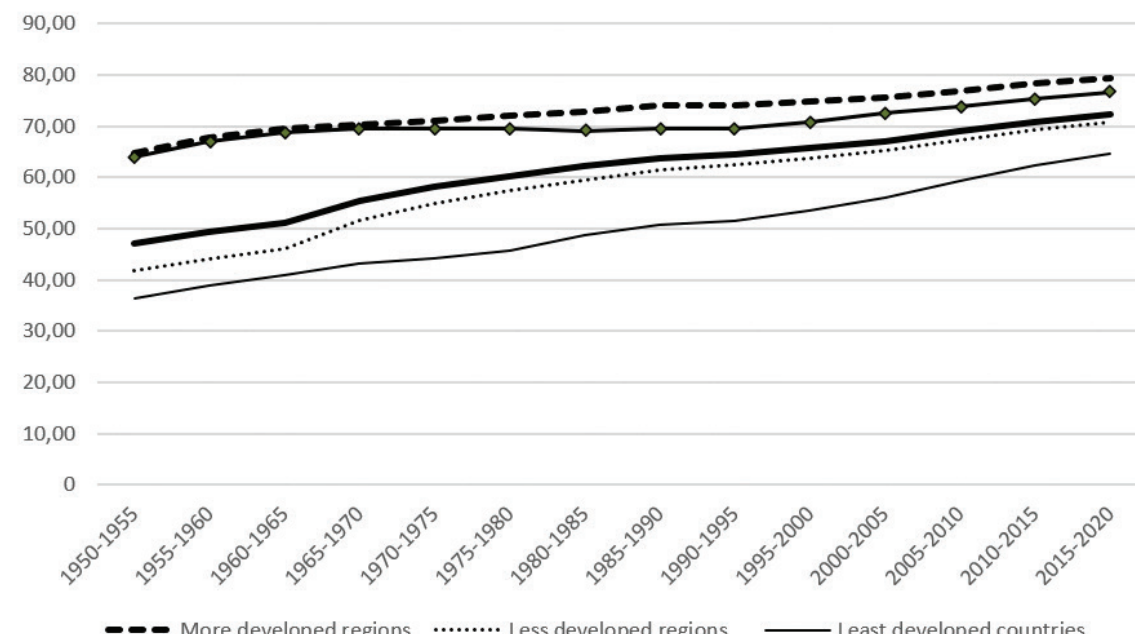

Forrás: UN World Population Propects 2019

https://population.un.org/wpp/Download/Standard/Mortality/ 
Ennek egyik legfontosabb következménye, hogy nő az egy bizonyos kor (pl. 60 vagy 65) felettiek aránya a népességen belül. ${ }^{2}$ Szokták ezt idősödésnek is nevezni, de nem biztos, hogy ez megalapozott elnevezés.

Logikailag ettől elkülönül, de szintén általánosan érvényes egy másik tendencia is az egész világon: mégpedig a TFR csökkenése, amit a 2. ábra mutat.

\section{2. ábra: TFR alakulása a világban}

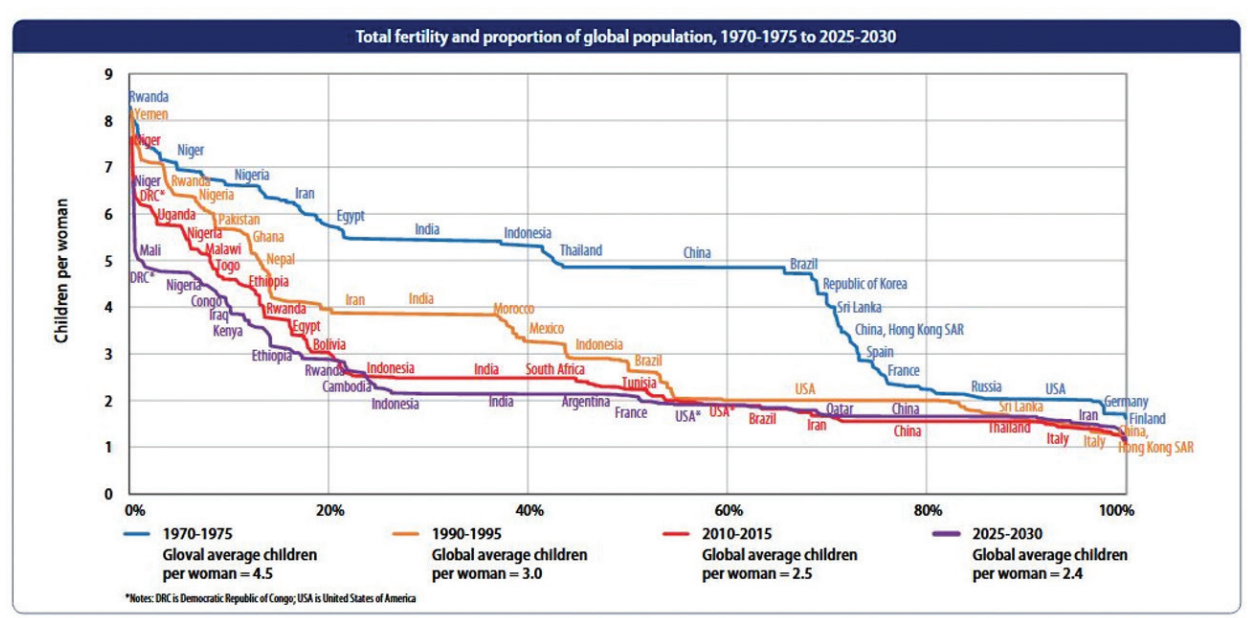

Forrás:UN [2015]

Maga a csökkenés általános, de abban nagy különbségek vannak, hogy hol tart az egyes országokban, illetve régiókban. Egyfajta vízválasztó a 2,1-es szám, ami azt jelenti, hogy ha a várható hátralévő élettartam állandó lenne, akkor emellett a TFR érték mellett lenne állandó a népességszám. Mivel a várható hátralévő élettartam növekszik, ezért az állandó népességszám ennél folyamatosan némileg kisebb TFR mellett is biztosítható. ${ }^{3}$

Jellemző ugyanakkor, hogy a legszegényebb fejlődő országok TFR értékei e fölött vannak (bár csökkennek), a fejletteké pedig szinte mindenhol ez alatt, némelyeké jóval.

A TFR csökkenése szintén a bizonyos kor feletti népesség arányának növekedését hozza, az élettartam növekedésétől függetlenül, illetve a két hatás erősíti egymást. Ezt viszont már sokkal inkább nevezhetjük öregedésnek, de inkább vizsgáljuk meg, hogy a kifejezést hogyan kell(ene) használni!

\section{MIT NEVEZHETÜNK ÖREGEDÉSNEK?}

Az öregedés szóhoz intuitíve az a kép társul, hogy egyre nő a korábbiakban magas korúnak tekintett, rossz egészségi állapotú, látványosan „öregnek” kinéző emberek aránya a népességben. Ugyanakkor tudjuk, hogy a mai 40-50-60 stb. évesek átlagosan sokkal „fittebbnek” és fiatalabbnak néznek ki, mint a fél évszázaddal ezelőtti akkor ennyi idősek. Tehát az, amit öregedésnek nevezünk, nem teljesíti ezt az intuitív képet. Célszerű ezért az „öregedés” kifejezést két értelemben használni:

$$
\text { minőségi és }
$$$$
\text { relatív öregedés, }
$$

és bizonyos mértékig összehangolni a két értelmet.

„Minőségi” öregedésnek pont azt nevezhetjük, ami a fenti intuitívöregedési elképzelést próbálja megragadni, vagyis azt a jelenséget, hogy az egészségi állapotunk mikor, hány éves kortól kezdve romlik le az öregséghez általánosan társított alacsonyabb szintre. A határt nevezhetjük minőségi öregedési korhatárnak - amit nyilván nehéz mérni, de nem lehetetlen. Ha például az történik, mint Swiftnél, akinél az örök élet (vagyis a várható hátralévő élettartam végtelenné növekedése) csak azt jelentette, hogy a rossz egészségi állapotú öregkor hosszabbodott meg végtelenre ${ }^{4}$, akkor a minőségi öregedési korhatár marad változatlan. Viszont a számok azt mondják, hogy ez nem igaz. A legközelebbi statisztika, ami erről mond valamit, a WHO statisztikája a várható egészséges élettartamról (HALE = Healthy life expectancy). Ezt ugyan még nem régóta számítják, de már van egyfajta idősora, vagyis elérhető két időpontra is: 2000-re és 2015-re. ${ }^{5}$ Ez alapján nem tűnik megalapozatlannak, ha azt gondoljuk, hogy a várható élettartam növekedésével nő a minőségi öregedési korhatár.

zelítőnek nézzük az 1. táblázatban a magyar és német uniszex adatokat - összehasonlításul idetettem a várható hátralévő élettartamokat.

1. táblázat: Német és magyar egészségesen várható élettartam alakulása

\begin{tabular}{|c|c|r|r|c|c|c|c|r|c|}
\hline Német & Kor & 2000 & 2015 & Növekedés & Magyar & Kor & 2000 & 2015 & Növekedés \\
\hline ex & 0 & 78,06 & 80,57 & 2,51 & ex & 0 & 71,76 & 75,66 & 3,9 \\
\hline HALE & 0 & 68,70 & 71,30 & 2,60 & HALE & 0 & 63,70 & 67,40 & 3,70 \\
\hline Különbség & & 9,36 & 9,27 & & Különbség & & 8,06 & 8,45 & \\
\hline ex & 60 & 21,73 & 23,36 & 1,63 & ex & 60 & 18,33 & 19,95 & 1,62 \\
\hline HALE & 60 & 16,90 & 18,60 & 1,70 & HALE & 60 & 14,10 & 15,80 & 1,70 \\
\hline Különbség & & 4,83 & 4,76 & & Különbség & & 4,23 & 4,40 & \\
\hline
\end{tabular}

Forrás: WHO, Global Health Observatory data repository, Human Mortality Database

A magyar és német adatok némileg mást mutatnak egymáshoz képest. Mindkét országban nőtt 15 év alatt mind a várható hátralévő összes, mind a várható hátralévő egészséges élettartam. Azonban, míg Németországban a várható hátralévő egészséges élettartam mindkét korra kicsit jobban nőtt a várható összesnél, addig Magyarországon az előbbi volt nagyobb mértékủ. Igaz, Magyarországon minden növekedés nagyobb volt a németnél az alacsonyabb bázis miatt. Mindenesetre az látszik, hogy idős korban sem alapvetően a betegeskedéssel néznek szembe egyik ország lakói sem. 
Ugyanakkor a fenti, bizonytalan mutató helyett célszerü bevezetni egy jobban számíthatót, amivel a mai általánosan alkalmazott fix vagy „abszolút” öregedési korhatárt (leggyakrabban 60, illetve 65 év) helyettesítjük, hiszen tudjuk, hogy a mai 60 éves átlagosan nem számít „olyan öregnek”, mint az 50 évvel ezelőtti, de feltehetőleg „öregebb”, mint a mostani 10 évesek lesznek 50 év múlva. ${ }^{6}$ Ezt az „abszolút”-ra való utalásként elnevezhetjük relatív öregedési korhatárnak, a lényege, hogy valamilyen általános feltételezést teszünk arra, hogy a fenti minőségi öregedési korhatár hogyan változik. A magam részéről a következő feltevésekből számított mindkét értéket el tudom képzelni - bár ezek különböző eredményeket adnak. Feltehetjük, hogy:

a) az átlagos emberi életpályának mindig ugyanakkora hányadát tölti az ember öregen, vagy

b) az átlagos emberi életpályából mindig ugyannyi évet töltünk öregen, vagyis azokat tekintjük öregeknek, akik olyan korba léptek, amikor a várható hátralévő élettartam egy fix szám.

Nevezhetjük az elsőt „fix \%”-nak, a másodikat pedig „fix $e$ ”-nek (ahol „e” a várható hátralévő élettartam szokásos jelölésére utal). Mindegyik esetben az történik, hogy a várható hátralévő élettartam növekedésével növekszik a relatív öregedési korhatár. Ha az elsősorban a fiatal és aktív korú népesség halandóságának javulása miatt következik be, akkor a fix \%, ha viszont elsősorban az időskorú népesség halandósága miatt, akkor a fix $e$ típusú érték nő jobban. Nyilván egy fejlett országban, amelyik nagyjából már kimerítette a fiatalkorú népesség halandóságának javításában rejlö potenciált (magyarán, ahol fiatalkorban már lényegében senki nem hal meg), ott már csak az időskorú népesség halandósága tud érdemben javulni, így ott általában a fix e mutató értéke lesz nagyobb.

Persze bevezethetünk a fentieknél komplikáltabb mutatókat is, amelyekben több tényezőt veszünk figyelembe. Mondjuk, azt tűzzük ki célul, hogy az aktív, járulékfizető évek és a passzív, járadékos évek aránya állandó maradjon. Ekkor azt is figyelembe kell venni, hogy mikor kezdődnek az aktív évek (ami manapság, a tanulmányok elhúzódása miatt egyre inkább kitolódik), és mennyire töredezett a munkavállalás. Ennek a megközelítésnek egy egyszerüsített változataként azért megnézhetö, hogy egy bizonyos életkor - pl. 18 év feletti élettartamból az öregen töltött évek aránya legyen állandó. Ezekkel a bonyolultabb lehetőségekkel egyelöre nem foglalkozunk itt, az áttekinthetőség kedvéért azért összefoglalom a 2. táblázatban a használt korhatár fogalmakat.

\section{2. táblázat: Az öregedési korhatár lehetséges értelmezései}

\begin{tabular}{|c|l|l|l|}
\hline \multirow{2}{*}{$\begin{array}{c}\text { minőségi öregedési } \\
\text { korhatár }\end{array}$} & $\begin{array}{l}|c| \\
\text { relatív öregedési korhatár }\end{array}$ \\
\cline { 2 - 4 } & $\begin{array}{l}\text { lyának mindig ugyanakkora } \\
\text { hányadát tölti az ember öregen }\end{array}$ & $\begin{array}{l}\text { az „x" év feletti élettartam- } \\
\text { ból az öregen töltött évek } \\
\text { aránya állandó }\end{array}$ & $\begin{array}{l}\text { fix e: az átlagos emberi élet- } \\
\text { pályából mindig ugyannyi } \\
\text { évet töltünk öregen }\end{array}$ \\
\hline
\end{tabular}

Forrás: saját szerkesztés
Nézzük meg röviden és szemléletesen, hogyan lehet a két mutatót kiszámítani. A kiindulópontunk mindkettő esetében a kihalási rend, vagyis a halandósági tábla kulcsoszlopa, amiből a többi származtatható. Lényege egyszerű: 100.000 egyidőben megszülető (tehát 0 éves) csecsemőből hány van még életben $1,2, \ldots$ stb. éves korban (jele: $l_{x}$ ). Ha ezt görbeként ábrázoljuk, akkor azt mondhatjuk, hogy az ez alatti terület egy bizonyos $x$ életkortól nem más, mint az $l_{x}$ akkor még életben lévő által még megélendő életévek összesége. Ebből következik, hogy az x éves korban várható hátralévő élettartam ennek a területnek és magának az $l_{x}$-nek a hányadosa. A fix \%-ot pedig az alábbi ábrával világíthatjuk meg. A 3. ábrán azt mutatom be, hogy az 1995-ös kihalási rend szerint 62 évesen még az induló élettartam A\%-a van hátra, de ez az A\% 2015-ben már jóval magasabb életkornál van.

3. ábra: A fix \% szemléltetése a kihalási renddel

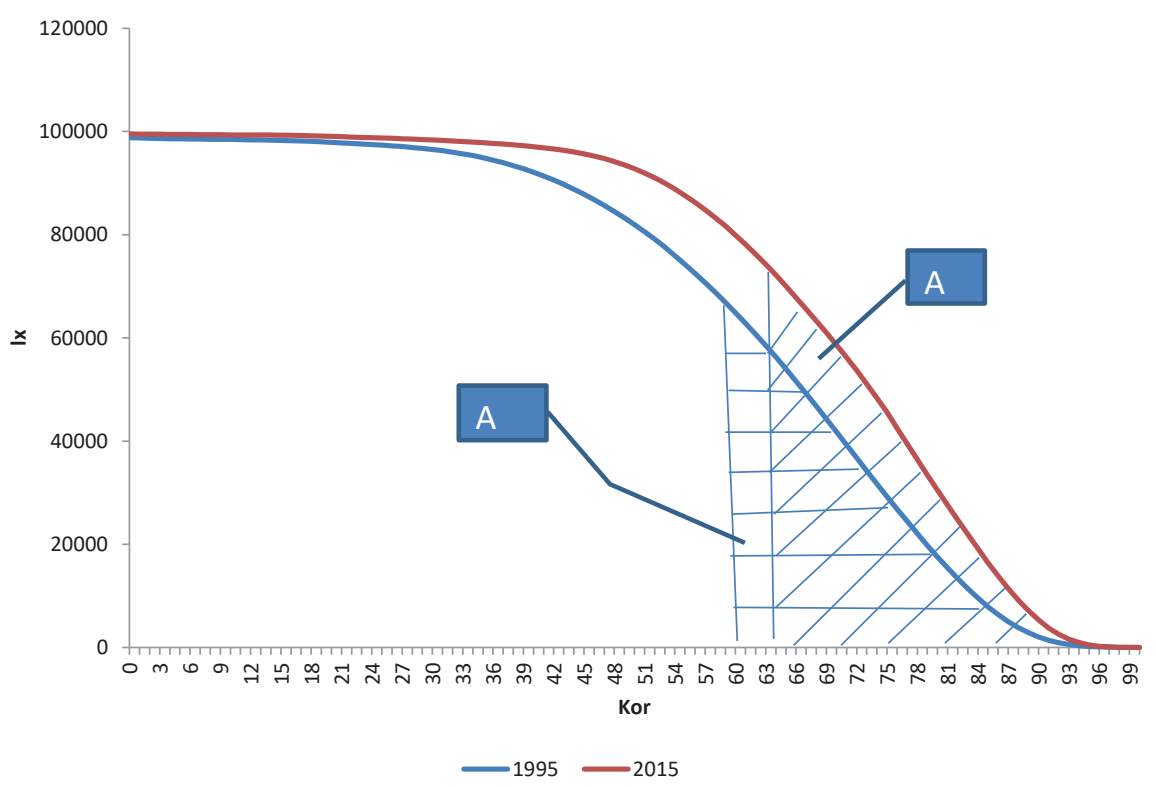

Forrás: saját számitás a mortality.org adatai alapján

A fix $e$ esetében azonban nem közvetlenül a kihalási rend görbéből kell kiindulnunk, hanem ezt transzformálnunk kell a várható hátralévő élettartam $\left(e_{x}\right)$ görbévé. A várható hátralévő élettartam $x$ éves korban pedig nem más, mint az ennyi idős korban még hátralévő összes életévek ( $a z l_{x}$ alatti terület) osztva magával az $l_{x}$-el. Ekkor minden egyes évre kapunk egy negatív meredekségű görbét. A javulás itt abban nyilvánul meg, hogy egy másik év görbéje ehhez képest felfele eltolódik (és persze valamennyire az alakja is 
megváltozhat). Ekkor azt keressük, hogy egy régebbi $e_{x}$ görbénél egy konkrét életkorhoz tartozó konrét várható hátralévő élettartamhoz az újabb görbénél milyen kor tartozik, mint ahogy azt a 4. ábra mutatja.

\section{4. ábra: A fix e szemléltetése a várható hátralévő élettartam görbékkel}

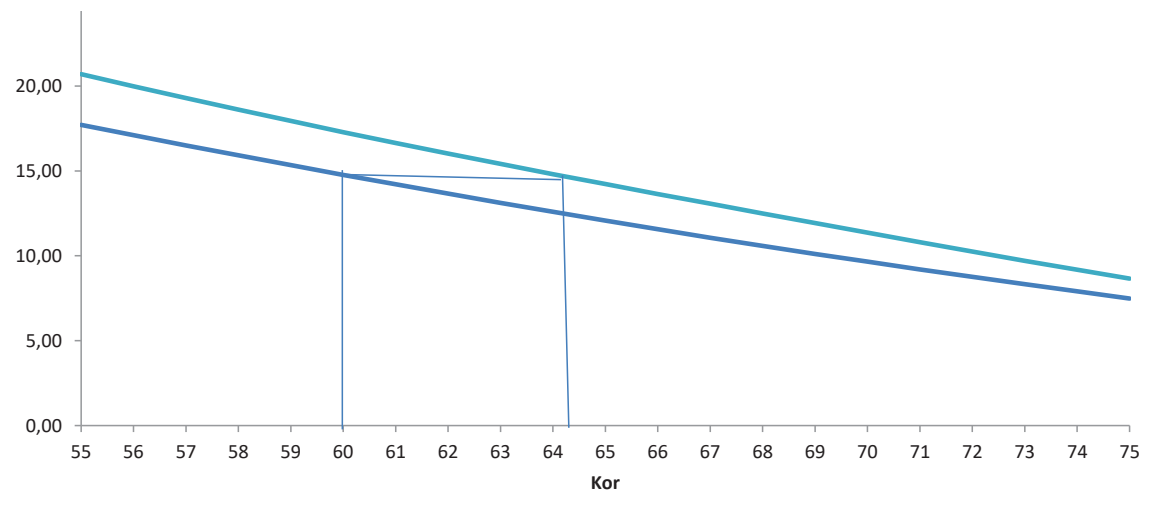

Forrás: saját számítás a mortality.org adatai alapján

Talán ebből a fenti leírásból is látszik, hogy ha választani kell a fix \% és a fix $e$ között, akkor a könnyű számolhatóság miatt az elsőt célszerű preferálni, hiszen ott az elsődleges adatokból, az $l_{x}$-ből, és nem annak transzformáltjából kell kiindulni. A második (némileg nehezebben számolható mutató) mellett szól ugyanakkor az, hogy az öregedésnél nem igazán számítható lényeges mozzanatnak, ha az idősek aránya amiatt változik, mert a fiatalkorú népesség halandósága változik. A fix e mutatóban viszont csak az érintett, időskorú népesség halandóságát veszik figyelembe, így az tartalmilag jobban kifejezi a lényeget. Ugyanakkor a gyakorlatban a két érték viszonylag közel van egymáshoz, így elképzelhető praktikus kompromisszumként a könnyen számolható fix \% mutató alkalmazása (ami - mint az előbb már láttuk - fejlett országokban már némileg alulméri a relatív öregedési korhatárt).

Ha meg is állapodtunk abban, hogy a továbbiakban valamelyik relatív öregedési mutatót alkalmazzuk, vagyis lényegében indexáljuk az öregségi korhatárt, még mindig megmarad a kérdés, hogy konkrétan mi legyen a kezdő érték, amit azután folyamatosan karbantartunk? Egy logikus lehetőség erre, hogy a múltban választunk egy időpontot, aminek a viszonyait jól ismerjük, és megállapítjuk azt a korhatárt, ami fölött akkor öregnek lehetett tekinteni az átlagos embert. Ezután fix \% esetben rögzítjük, hogy az átlagos ember akkor, életpályája hány \%-át töltötte öregen, $\mathrm{s}$ a későbbiekben minden évben megkeressük azt az életkort, ami mellett az adott népesség átlagos embere életpályája ugyanekkora részét tölti ennél idősebben. A fix e esetben pedig minden későbbi évben azt a kort keressük, amitől kezdve az átlagos ember ugyanakkora hosszúságú időt tölt öregen (fejlett országokban az előbbihez képest ekkor az öregen töltött idő aránya csökken, míg ott ennek aránya állandó).
Természetesen ez a mostani gyakorlathoz képest bonyolultabbá teszi a nemzetközi összehasonlításokat, több számítást kell végezni, de a dolog nem lehetetlen. Viszont ennek eredményeképpen a relatív öregedési korhatár minden évben más lesz egy országban, és egy éven belül más-más lesz különböző országoknál.

A nemzetközi sztenderdizálást legkönnyebben a fix \% feltevés alapján számított mutatóval lehet elérni. Ekkor úgy célszerű eljárni, hogy - elözetes vizsgálódások alapján - kijelölünk egy vagy több arányt - mondjuk 15, 20 és 25\%-ot - amit az átlagos élettartamból időskornak tekintünk, s minden országban ezt a 20\%-ot vizsgáljuk a rendelkezésre álló élettartam-statisztikák alapján.

Nézzünk néhány konkrét adatot! Mivel a társadalombiztosításban nem tesznek különbséget férfi és nő között, ezért az uniszex halandóságot vizsgálom, illetve annak változását, ismét ugyannak a két országnak, Magyarországnak és Németországnak a példáján, mint az előbb (lásd 3. táblázat), kezdve a magyar adatokkal!

3. táblázat: Magyar uniszex várható hátralévő élettartamok különböző korokra és különböző években

\begin{tabular}{|c|c|c|c|c|c|c|}
\hline \multicolumn{7}{|c|}{ Magyar uniszex várható $e_{x}$-ek különböző években } \\
\hline Kor & 1990 & 1995 & 2000 & 2005 & 2010 & 2015 \\
\hline 0 & 69,38 & 69,98 & 71,76 & 72,88 & 74,54 & 75,66 \\
\hline 60 & 17,12 & 17,51 & 18,33 & 18,84 & 19,61 & 19,95 \\
\hline 61 & 16,46 & 16,86 & 17,65 & 18,14 & 18,92 & 19,25 \\
\hline 62 & 15,8 & 16,21 & 16,97 & 17,46 & 18,24 & 18,55 \\
\hline 63 & 15,16 & 15,56 & 16,31 & 16,78 & 17,57 & 17,86 \\
\hline 64 & 14,54 & 14,93 & 15,66 & 16,1 & 16,9 & 17,2 \\
\hline 65 & 13,91 & 14,3 & 15,01 & 15,44 & 16,22 & 16,53 \\
\hline fix e 60-tól & 60 & 60,60 & 61,78 & 62,50 & 63,67 & 64,12 \\
\hline Növekedés & & 0,60 & 1,18 & 0,72 & 1,17 & 0,45 \\
\hline \multicolumn{7}{|c|}{ Magyar uniszex $e_{x}$-ek az $e_{0} \%$-ában - különböző években } \\
\hline 60 & $18,88 \%$ & $19,11 \%$ & $20,35 \%$ & $20,96 \%$ & $22,03 \%$ & $22,76 \%$ \\
\hline 61 & $17,79 \%$ & $18,03 \%$ & $19,25 \%$ & $19,85 \%$ & $20,92 \%$ & $21,63 \%$ \\
\hline 62 & $16,72 \%$ & $16,97 \%$ & $18,17 \%$ & $18,77 \%$ & $19,82 \%$ & $20,51 \%$ \\
\hline 63 & $15,67 \%$ & $15,93 \%$ & $17,11 \%$ & $17,70 \%$ & $18,75 \%$ & $19,42 \%$ \\
\hline 64 & $14,65 \%$ & $14,92 \%$ & $16,07 \%$ & $16,66 \%$ & $17,69 \%$ & $18,34 \%$ \\
\hline fix \% 60-tól & 60 & 60,21 & 61,34 & 61,90 & 62,87 & 63,5 \\
\hline Növekedés & & 0,21 & 1,13 & 0,55 & 0,98 & 0,62 \\
\hline \multicolumn{7}{|c|}{ A várható hátralévő élettartam növekedése az 1990-es értékhez képest } \\
\hline 0 & $100 \%$ & $101 \%$ & $103 \%$ & $105 \%$ & $107 \%$ & $109 \%$ \\
\hline 60 & $100 \%$ & $102 \%$ & $107 \%$ & $110 \%$ & $115 \%$ & $117 \%$ \\
\hline
\end{tabular}

Forrás: mortality.org és saját számitás 
A 3. táblázat a magyar uniszex néphalandósági táblázatból származó néhány értéket mutat 1990-től kezdve 5 éves időközönként. A fix e 60 és a fix \% 60 saját számítás, amit úgy végeztem el, hogy megnéztem, 1995-ben és később mely életkoroknál érjük el ugyanazt az értéket, ami a 60 évesekre 1990-ben jellemző volt. Ekkor - a táblázat alapján - 60 éves korban a várható hátralévő élettartam 17,12 volt, illetve ekkor arra lehetett számítani, hogy az átlagos ember élettartamának 18,88\%-át tölti 60 éves kor fölött. Ráadásul ekkor 60 év volt a nyugdíjkorhatár is. A fix e 60 és a fix \% 60 értékek kiszámításánál ezeket vettem adottnak. 1995-ben például 60 éves korban már 17,51-re nőtt a várható hátralévő élettartam, de 61 éves korban már csak 16,86 volt. Ezt a két értéket a táblázatban besötétítettem, mert az a kor, amikor pont 17,12 volt a várható hátralévő élettartam, e közé a kettő közé esik. Ezt végül arányosítással számítottam ki, így jött ki a fix e 60 sorban szereplő 60,60 érték. A többi számnál, illetve a fix \% 60-nál is így jártam el. Az eredmény az lett, hogy 25 év alatt 60-ról 64,12 évre nőtt az a kor, amikor az induló 17,12 év volt még mindig a várható hátralévő élettartam (vagyis a fix $e$ korhatár), illetve 63,5-re az a kor, amikor egész élettartamunk 18,8\%-át töltjük ennél idősebben (vagyis a fix \% korhatár). Nem lepődtünk meg, hogy az első érték magasabb, mint a második, hiszen mostanra a magyar kihalási rend is a fejlett országokra jellemző vonást mutatja, vagyis a várható hátralévő élettartam növekedésének fiatalkori forrásai nagyrészt kimerültek, amit a táblázat két utolsó sora jól mutat. Eszerint a 60 évesen várható hátralévő élettartam relatíve sokkal gyorsabban nőtt, mint a születéskor várható hátralévő élettartam.

A fenti eredményeket mutatja az 5. ábra is, ahova berajzoltam a 65 éves értékeket is:

\section{5. ábra: A relatív öregedési korhatárok változása}

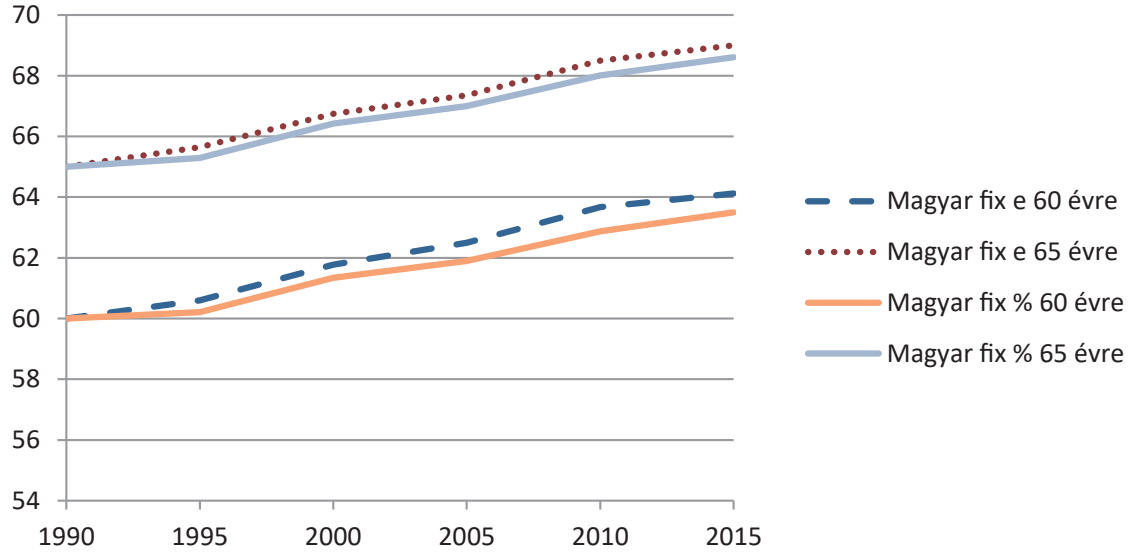

Forrás: mortality.org és saját számítás

Látszik, hogy a fix e relatív korhatár ugyan nem egyenletesen, de nagyjából (kicsit nagyobb, mint) 2 hónap/ év ütemben nőtt. Ennyivel tehát nyugodtan indexálni lehetett volna a nyugdíkorhatárt, amit végül meg is tettek, igaz, mire az eléri a 65 évet, nyugodtan lehet folytatni a további emelést.
Most nézzük meg a 4. táblázatban a német adatokat!

4. táblázat: Uniszex várható hátralévő élettartamok különböző korokra és különböző években

\begin{tabular}{|c|c|c|c|c|c|c|}
\hline \multicolumn{7}{|c|}{ Német uniszex várható ó o $e_{x}$-ek különböző években } \\
\hline Kor & 1990 & 1995 & 2000 & 2005 & 2010 & 2015 \\
\hline 0 & 75,35 & 76,56 & 78,06 & 79,26 & 80,09 & 80,57 \\
\hline 60 & 19,9 & 20,7 & 21,73 & 22,56 & 23,11 & 23,36 \\
\hline 61 & 19,14 & 19,92 & 20,93 & 21,74 & 22,29 & 22,54 \\
\hline 62 & 18,39 & 19,14 & 20,13 & 20,93 & 21,48 & 21,73 \\
\hline 63 & 17,64 & 18,38 & 19,34 & 20,13 & 20,67 & 20,92 \\
\hline 64 & 16,9 & 17,64 & 18,56 & 19,34 & 19,88 & 20,13 \\
\hline 65 & 16,16 & 16,91 & 17,78 & 18,54 & 19,08 & 19,34 \\
\hline 66 & 15,44 & 16,19 & 17,04 & 17,76 & 18,3 & 18,57 \\
\hline 67 & 14,73 & 15,49 & 16,3 & 16,99 & 17,53 & 17,8 \\
\hline 68 & 14,02 & 14,8 & 15,58 & 16,23 & 16,76 & 17,04 \\
\hline 69 & 13,34 & 14,11 & 14,88 & 15,48 & 16 & 16,29 \\
\hline 70 & 12,67 & 13,43 & 14,18 & 14,75 & 15,24 & 15,53 \\
\hline fix e 60-tól & 60 & 61,03 & 62,29 & 63,29 & 63,97 & 64,29 \\
\hline Növekedés & 65 & 66,04 & 67,19 & 68,09 & 68,79 & 69,17 \\
\hline \multicolumn{7}{|c|}{ Német uniszex $e_{x}$-ek az $e_{0} \%$-ában - különböző években } \\
\hline 60 & $23,02 \%$ & $23,91 \%$ & $25,03 \%$ & $25,88 \%$ & $26,47 \%$ & $26,79 \%$ \\
\hline 61 & $21,87 \%$ & $22,76 \%$ & $23,88 \%$ & $24,74 \%$ & $25,33 \%$ & $25,65 \%$ \\
\hline 62 & $20,74 \%$ & $21,62 \%$ & $22,75 \%$ & $23,61 \%$ & $24,20 \%$ & $24,51 \%$ \\
\hline 63 & $19,62 \%$ & $20,50 \%$ & $21,62 \%$ & $22,48 \%$ & $23,07 \%$ & $23,39 \%$ \\
\hline 64 & $18,51 \%$ & $19,39 \%$ & $20,51 \%$ & $21,37 \%$ & $21,96 \%$ & $22,28 \%$ \\
\hline 65 & $17,43 \%$ & $18,30 \%$ & $19,41 \%$ & $20,27 \%$ & $20,86 \%$ & $21,18 \%$ \\
\hline 66 & $16,36 \%$ & $17,23 \%$ & $18,33 \%$ & $19,19 \%$ & $19,78 \%$ & $20,09 \%$ \\
\hline 67 & $15,31 \%$ & $16,18 \%$ & $17,26 \%$ & $18,11 \%$ & $18,70 \%$ & $19,01 \%$ \\
\hline 68 & $14,28 \%$ & $15,14 \%$ & $16,21 \%$ & $17,06 \%$ & $17,64 \%$ & $17,95 \%$ \\
\hline 69 & $13,27 \%$ & $14,13 \%$ & $15,18 \%$ & $16,01 \%$ & $16,60 \%$ & $16,91 \%$ \\
\hline 70 & $12,29 \%$ & $13,14 \%$ & $14,17 \%$ & $14,99 \%$ & $15,57 \%$ & $15,88 \%$ \\
\hline fix \% 60-tól & 60 & 60,77 & 61,76 & 62,52 & 63,05 & 63,33 \\
\hline Növekedés & 65 & 65,82 & 66,85 & 67,65 & 68,21 & 68,50 \\
\hline \multicolumn{7}{|c|}{ A várható hátralévő élettartam növekedése az 1990-es értékhez képest } \\
\hline 0 & $100 \%$ & $102 \%$ & $104 \%$ & $105 \%$ & $106 \%$ & $107 \%$ \\
\hline 60 & $100 \%$ & $104 \%$ & $109 \%$ & $113 \%$ & $116 \%$ & $117 \%$ \\
\hline
\end{tabular}

Forrás: mortality.org és saját számitás 
A német adatok teljesen analógok a magyarokkal azzal, hogy egy nagyon kicsit itt kisebb az emelkedés, de ez érthető is a jóval magasabb bázis miatt. Itt is érvényes, hogy idősebb korban nagyobb volt a várható hátralévő élettartam növekedése, így a fix e relatív korhatárok érzékelhetően magasabbak voltak, mint a fix \% korhatárok. Ugyanakkor az is látszik, hogy - ha elfogadhatónak tartjuk az 1990-es magyar 60 éves nyugdíjkorhatárt, amikor 17,12 év volt a várhatóan nyugdíjban töltött idő, akkor - Németországban már 1990-ben több, mint 63,5 évnek kellett volna lennie a nyugdíjkorhatárnak, aminek mára majdnem 68 éves korig kellett volna indexálódnia.

A fentiek alapján összességében azt mondhatjuk, hogy ha ezt az indokolt, relatív öregedési korhatár mutatót bevezetjük, akkor ez azzal jár, hogy az élettartam általános meghosszabbodása önmagában nem okoz öregedést, tehát amit fent első értelemben neveztünk öregedésnek, az nem lesz többé az. Ez azt is jelenti, hogy ha a TFR pont 2,1 lesz, akkor az (így értett) (fix \% típusú, „relatív”) öregek aránya nem fog nőni (az amúgy növekvő) népességen belül, ha efölötti, akkor csökkenni fog, ha kisebb, akkor nőni. Másképp: ekkor a relatív öregedés egyedül a TFR értékéktől fog függeni. Sőt - mint láttuk - az történik, hogy (fejlett országoknál) a fix e típusú relatív öregedésnél még némileg 2,1 TFR alatt sem fog nőni az öregek aránya, vagyis az aktív élettartam növekedése valamennyi meg nem született gyermeket is „kivált”.

Remélhető, hogy a jövőben rendelkezni fogunk egy többé-kevésbé korrekt módszerrel, amivel meg tudjuk majd mérni a minőségi öregedési korhatárt - s ez alapján tudunk választani a lehetséges relatív mutatók között, vagy esetleg egy egészen mást készíthetünk. A jó eset, hogy a minőségi öregedési korhatár gyorsabban nő, mint a relatív, a rossz ennek a fordítottja. Az előbbi esetben minőségi értelemben fiatalodásról is lehet beszélni.

Intuitíve azt lehet mondani, hogy a relatív öregedési korhatárnál gyorsabban növő minőségi öregedési korhatárt (a minőségi fiatalodást) eleve az indokolja, ami magát a várható élettartam növekedését, vagyis a népesség egyre jobb egészségi állapota. Az ellenkező tendenciát pedig, vagyis a minőségi öregedést az, hogy az orvostudomány fejlődésével egyre tovább tudják betegen életben tartani az embereket, mint korábban, bár nem ez a cél, hanem, hogy egészségessé tegyék őket. A kettő egyensúlya a két ráta hasonló növekedési üteme, hiszen ekkor abszolút értelemben mind az egészséges élettartamunk, mind a betegen töltött élettartamunk nő.

Mivel a minőségi öregedési korhatárról nincsenek jó információink, a továbbiakban az egyszerüség kedvéért ezt az egyensúlyi növekedési ütemet feltételezem, vagyis a két ráta (a relatív és a minőségi) egyenlő növekedési ütemét, amelyek közül az elsőre már ma lehetséges számításokat végezni.

A relatív öregedési korhatárra való áttérés azt jelenti, hogy a (potenciális) aktívan töltött időtartam nő az időskorral együtt, vagy azzal szemben. Persze ez azt feltételezi, hogy nem növekszik közben az első inaktív kor, vagyis az iskolában töltött idő, amire azonban szintén van tendencia.
AZ ÉLETTARTAM MEGHOSSZABBODÁSA MIATTI PÉNZÜGYI PROBLÉMÁK A TB-BEN

\section{KORHATÁR-INDEXÁLÁS}

A TB két fö ágának, a nyugdíj- és az egészségbiztosításnak a finanszírozása nemzetközileg (így Magyarországon is) a következő mintát követi: amíg az emberek aktívak, vagyis dolgoznak és munkabért kapnak, addig befizetnek a rendszerbe, amikor pedig nyugdíba mennek, akkor csak kifizetéseket, illetve szolgáltatásokat kapnak onnét. (Ettől csak kevés kivétel van, amikor a nyugdíj mellett dolgoznak, és valamennyi járulékot is fizetnek.) A szolgáltatások tekintetében eltér egymástól a nyugdij- és az egészségbiztositás annyiban, hogy az előbbiben a szolgáltatás csak a nyugdíjba vonulás után kezdődik, míg utóbbiban az aktív évek alatt (sőt előtte) is, igaz, a nyugdíjas években ez a szolgáltatás sokszorosa lehet az aktív években igénybe vettnek. Vagyis alapvetően itt is igaz, hogy az aktuális aktívak „tartják el” az aktuális nyugdíjasokat. Emiatt nagyon fontos, hogy hogyan alakul az idős inaktív-aktív arány, amire az élettartam meghosszabbodásának erős ráhatása van.

Az élettartam meghosszabbodásának nem kellene olyan erős hatásúnak lennie, mint ahogyan az sok TB-rendszerben jelentkezik.

A fenti elemzés fényében azonban azt mondhatjuk, hogy az élettartam meghosszabbodásának nem kellene olyan erős hatásúnak lennie, mint ahogyan az sok TB-rendszerben jelentkezik. Általános ugyanis, hogy az öregségi nyugdíjkorhatár hosszú ideig merev, vagyis az élettartam meghosszabbodása lényegében a nyugdíjas (járadékot kapó, egészségügyi járulékot nem fizető) élettartam növekedésében csapódik le, ami önmagában is rontja a TB mindkét ágának a pénzügyi helyzetét. A hosszú ideig mozdulatlan nyugdijkorhatár elméleti alapjai azonban ingatagok, inkább egyfajta gondolati restség, illetve (ezúttal politikai jellegű) tehetetlenség (inercia) van mögötte. Ugyanakkor ezt már sok országban felismerték, és bevezettek egyfajta automatikus korhatár-indexálást a nyugdíjrendszerbe, sőt az EU is ezt ajánlja már mint jó gyakorlatot (EC [2012]). Ugyanakkor ez az ajánlás nagyon óvatosan fogalmaz, és nem annyira a rendszeres nyugdíjkorhatár-indexálást, mint inkább a nyugdíjkorhatár időnkénti élettartam-növekedéshez való hozzáigazítását javasolja, néhány országot is megemlít ennek kapcsán (Csehország, Görögország, Franciaország, Olaszország), bár nem világos, hogy ők pontosan milyen módszert követnek, illetve hogy valamelyiket-e a fent tárgyalt kettő közül.

A korhatár-indexálás praktikus részére rátérve nyilván az a legegyszerűbb megoldás, hogy az indexálás előre rögzített lépésekben (pl. évente 2 hónappal) történjen, a tényleges változást csak időnként ellenőrzik, s ha szükséges, igazítják hozzá a fix lépéses indexálás mértékét ehhez. Mindenesetre ez így észszerű kompromisszumnak tűnik a kiszámíthatóság és az elvi megalapozottság között, azzal, hogy így kisebb „hatókörben”, de megmaradt a régi módszer egy eleme, ahol is a rendszeres indexálás helyett „kampányszerü” korhatáremelésekre került sor. 
(Itt a kampány a korhatár-változtatás ütemének változására vonatkozik már csak.) Ugyanakkor valami elvi alapot (vagyis a relatív öregedési korhatár kiszámításának elvét) így is választani kell, hogy legyen mihez mérni azt, hogy a gyakorlati indexálás és az elvi „elcsúszott”-e egymástól.

Ahol a nyugdíjkorhatár automatikus indexálását meglépik, ott a TB pénzügyi helyzetének romlásából kiküszöbölik azt a tényezöt, amit maga a TB okoz, mondhatni, ahol az a saját lábában botlik meg. Innentől kezdve maga az élettartam-emelkedés a TB pénzügyi helyzetét tekintve semleges lesz, így csak két másik lényeges tényező marad, ami ronthat a helyzeten:

1. a TFR tartósan 2,1 alatti szintje

2. az orvostudomány olyan fejlődése, ami egyre tovább tud betegen életben tartani időseket, hiszen ez folyamatosan egyre több kezelést és ráfordítást jelent. (Ez lényegében a minőségi öregedési korhatár lassú növekedését, esetleg csökkenését jelenti.)

Ugyanakkor, ha jobban megvizsgáljuk a két indexálási lehetőséget, és kiegészítjük egy olyan feltevéssel, ami az átlagos munkába lépési korra vonatkozik, akkor azt mondhatjuk, hogy a TFR legalább 2,1-es szintje csak akkor kell a TB pénzügyi problémáinak kezeléséhez, ha a fix \% típusú indexálásnál a munkába állási kor is olyan ütemben növekszik, mint a relatív öregedési korhatár. Ha ennél kisebb mértékben, akkor alacsonyabb TFR is elég. Még jobb lesz a helyzet, ha fix $e$ típusú indexálásra térünk át. Vagyis a TFR-nek a népesség újratermeléséhez szükségesnél alacsonyabb szintjét egy bizonyos mértékig (mondjuk 1,8-ig, de ehhez pontos számítások szükségesek) kompenzálni tudja a relatív öregségi korhatár megfelelő mértékének a bevezetése és a munkába állási kor moderált emelkedése.

Itt nagyon fontos megemlíteni, hogy maga az, hogy áttérhetünk-e a fix e típusú indexálásra (ahol a problémák csak nagyon alacsony - 2,1-nél jóval alacsonyabb - TFR esetén éleződnek ki), erősen függ olyan „környezeti” feltételektől, mint a munkáltatás jellege. A jelenlegi foglalkoztatás olyan, hogy aktív korban némileg „túlhasználják”, és ezzel „elhasználják” a munkavállalót, ami a minőségi öregedési korhatárt lefele nyomja. Ennek legfőbb oka az évi viszonylag magas munkaórák száma. Ráadásul a nyugdíjba vonulással ez egy csapásra csökken le a lehető legalacsonyabb szintre. Ez így biztosan nem racionális, ugyanazt az életpálya munkaidőt hosszabb idő alatt, egyenletesebben lehetne elosztani. Ezáltal az történne, hogy tovább meg tudnánk élni a folyó jövedelmünkből, és csak rövidebb időre szorulnánk rá másokra vagy saját korábbi felhalmozásunkra. Ha kevesebbet, de tovább dolgoznánk, akkor jobban illeszkedne egymáshoz a jövedelmünk és a fogyasztásunk, vagyis viszonylag kevesebb folyó jövedelem is elég lenne, hiszen kevesebbet kellene belőle a későbbiekre félretenni. És feltehetőleg tovább egészségesek és munkaképesek maradnánk, hiszen többet tudnánk pihenni és az egészségünkkel foglalkozni. (Ezt célozza a mexikói milliárdos Carlos Slim javaslata, amit saját üzemeiben meg is valósított Bloomberg Businessweek [2016], illetve magam is részletesen kifejtettem ezt már - lásd Banyár [2016]). Ez ráadásul az automatizálás miatt szükülő munkaalkalmak újraelosztását is jelentené, vagyis hatékony védelem lenne a munkanélküliség ellen. Azzal, hogy csökkenti a hosszú távú nyugdíj-megtakarítás szükségességét, azonnal elkölthető jövedelmekké transzformálja ezeket a megtakarításokat, aminek munkahelyteremtő hatása van, különösen a szolgáltatási szektorban, aminek a jelentősége a megnövekedett szabadidővel maga is megnövekedne, és amit - mivel munkaintenzívebb - kevésbé veszélyeztet az automatizálás. S hogy még egy visszacsatolást említsünk: a munkaidő csökkentése több lehetőséget ad egészségünk megőrzésére, s ezzel arra, hogy a minőségi öregedési korhatár gyorsabban növekedjen, mint a relatív öregedési korhatárok. Ugyanakkor ez a visszacsatolás nem automatikus, függ attól, hogy hogyan töljük azt a több szabadidőt, sportolással vagy a TV előtt pizzázva/sörözve, vagyis a több szabadidő akár még rontani is tud egészségi helyzetünkön, ha rosszul használjuk ki.

\section{TOVÁBBI LEHETŐSÉGEK}

Magát a szúken vett longevity problémát lehet kezelni a korhatárindexálással, főleg ha azt a minőségi öregedési korhatár emelkedése alátámasztja - mint azt vélelmeztük.

Emiatt az idősek számának relatív növekedését - ha még így is jelentkezik - kizárólag a TFR alacsony szintje okozza. A TB szempontjából, ha feltételezzük, hogy a finanszírozási modell változatlan, vagyis az aktívak járulékai tartják fenn mind a nyugdíj-, mind az egészségbiztosítási rendszert, és az így befolyt járulékot a mostani elvek szerint osztják el (vagyis a nyugdíjak esetében az egyéni járulékfizetés alapján), akkor ez csökkenő nyugdíjakat és romló színvonalú egészségügyi ellátást jelent. Ha ebbe nem törődünk bele, és nem akarunk színvonalromlást, akkor a következő lehetőségeink adódnak - ha eltekintünk a be- és kivándorlástól (arról alább):

\section{A járulékszint emelése a rövid távú, kapkodó \\ politikai alternatíva.}

1. Egyre növeljük a járulékszintet (itt most egységesen kezelve a munkavállalótól és a munkáltatótól levont részt, bár a kettőt egy mélyebb elemzésnél érdemes megkülönböztetni), vagyis a finanszírozási problémát mint tehernövelést áttoljuk az újabb generációkra. Ezzel nem az idős generáció életszínvonalát csökkentjük, hanem a fiatalét.

2. Megpróbáljuk növelni a TFR-t, vagy más módon pótolni a hiányzó aktívakat.

3. Előtakarékoskodunk a hiányzó ellátásokra, vagyis részlegesen feltőkésítjük a TB-t.

(Másképp: most csökkentjük kicsit az életszínvonalat, hogy később ne csökkenjen nagyon. ${ }^{8}$ )

Ezek rég ismert alternativák, azonban úgy gondolom, hogy eddig túlságosan mechanikusan kezelték a témát, és a fö irányokon belül nem vették észre a lényegi alternatívákat. Ez különösen a 3. irányra, az egyetlen igazi alternatívára igaz. Azért röviden emlékezzünk meg az első kettőről, mielőtt áttérünk a harmadikra.

A járulékszint emelése a rövid távú, kapkodó politikai alternatíva. Demokráciákban, ahol a hosszú táv egy választási ciklus hosszát jelenti, gyakori, hogy az ennél hosszabb távon megoldandó problémákra ilyen kapkodó válaszokat adnak. Ennek ellenére ez a megoldás problémás, mert az érintett fiatalokat ellenakciókra készteti. Ez lehet direkt politikai is - pl. elveszik a szavazati jogot az öregektől (mondjuk úgy, hogy azt adófizetéshez kötik), vagy csökkentik súlyukat úgy, hogy a szavazatot súlyozzák a szavazó várható hátralévő élettartamával, vagyis hogy meddig 
kell együtt élnie döntésével, vagy hogy szavazatot adnak a gyermekeknek is, stb. - vagy indirekt. Ez utóbbi az egyre növekvő kivándorlás, vagyis ezen a módon a fiatalok kivonják magukat a járulékfizetés alól, még inkább súlyosbítva a TB finanszírozási problémáit. Az eredmény nem feltétlenül az öregek csökkenő életszínvonala lesz azonnal, inkább egy egyre jobban leépülő állam, illetve társadalom. (lásd pl. Madár [2017], ahol Holtzer Péter mondja el azt, amit én Fehér Csabától hallottam, mint gyakorlati megfigyelést bizonyos nehéz fiskális helyzetben lévő balkáni országokkal kapcsolatosan. A megfigyelés lényege, hogy a nyugdíjakat fizetik a legtovább, minden másállami kifizetéssel - pl. oktatásügy, egészségügy stb. - előbb felhagynak. )

A TFR növelése nagyon sok országban napirenden van, az általános benyomás, hogy ennek a jó módszerére még nem igazán jöttek rá, az eddigi erőfeszítések viszonylag csekély eredményt hoztak. Ha jobban megvizsgáljuk azoknak a fejlett országoknak az adatait, ahol a TFR közel van a 2,1-hez, ott is azt tapasztaljuk, hogy azt főleg az alacsony iskolázottságú bevándorlók magas fertilitása emeli relatíve magas szintre. Ez pedig nem biztos, hogy jó megoldás, mert ők hajlamosak továbbörökíteni saját alacsony iskolázottságukat, ami másképp azt jelenti, hogy gyermekeikből nem igazán válik jó járulékfizető az egyre inkább tudásalapú gazdaságokban. Álljon itt erről az 5. táblázat (Clovis Institute [2018]):

\section{5. táblázat: A muszlim és nem muszlim népesség fertilitása Európában}

\begin{tabular}{|c|c|c|c|}
\hline $\begin{array}{l}\text { Európai előreje } \\
\text { lakosság körébe } \\
\text { mint a nem-mu }\end{array}$ & $\begin{array}{l}\text { elzések } \\
\text { en több } \\
\text { uszlim } 1\end{array}$ & $\begin{array}{l}\text { erint a musz } \\
\text { yerek szület } \\
\text { cosságon be }\end{array}$ & \\
\hline Teljes fertilitási arán & nyszámok & 2015-2020 & \\
\hline & Muszlim & Nem-muszlim & \\
\hline Európai átlag & 2.6 & 1.6 & \\
\hline Finnország & 3.1 & 1.7 & \\
\hline Egyesült Királyság & 2.9 & 1.8 & $\begin{array}{r}+1.0 \\
+1.0\end{array}$ \\
\hline Franciaország & 2.9 & 1.9 & +1.0 \\
\hline Svájc & 2.8 & 1.8 & +0.9 \\
\hline Belgium & 2.6 & 1.7 & +0.9 \\
\hline Dánia & 2.5 & 1.7 & +0.8 \\
\hline Hollandia & 2.3 & 1.7 & +0.5 \\
\hline Austria & 2.2 & 1.5 & \\
\hline Norvégia & 2.1 & 1.8 & +0.3 \\
\hline Sváic & 2.1 & 1.5 & +0.6 \\
\hline Német & 1.9 & 1.4 & \\
\hline Írorsz & 1.8 & 2.0 & -0.2 \\
\hline Szlovénia & 1.7 & 1.6 & +0.1 \\
\hline & 1.6 & 1.6 & \\
\hline Románia & 1.6 & 1.5 & \\
\hline Görögország & 1.5 & 1.3 & +0.2 \\
\hline
\end{tabular}

Meglegyzés: A teljes fertilitás arányzzám (TFR) egy becsles a ayermenck

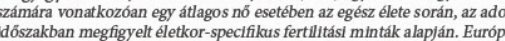

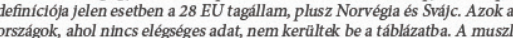

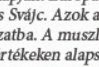

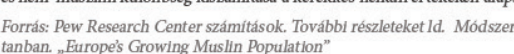

Forrás: Clovis Institute [2018]
Ebből következik, hogy a bevándorlás csak akkor megoldás, ha a bevándorlók megfelelően iskolázottak. A bevándorolni kész tömegek elsöprő többsége nem ilyen, tehát a bevándorlás csak akkor segít, ha

1. sikerül „lefölözni” a fejlődő országok kis létszámú intelligenciáját. Az Egyesült Államok jó ebben, de ez azt is jelenti, hogy lényegében mindenki mástól (így pl. az EU-tól is) elszívják ezt a réteget.

2. Marad tehát az egymástól csábítás. Az EU-n belül például manapság nagyban megy az, hogy a fejlett EU országok csábítják a közepesen fejlett EU országok fiataljait. Ezzel náluk oldódik az alacsony TFR miatti TB finanszírozási probléma azon az áron, hogy a közepesen fejletteknél ez hamarabb és jobban kiéleződik. (A Banyár [2014b]-ben ezt a gondolatot részletesebben kifejtem.)

Egy általános megoldás lehetne, ha találnánk olyan magas termékenységü területet a világban, ahonnét képzett munkaerőt lehetne importálni. Ilyen pillanatnyilag nincs, de például Európa számára kézenfekvő lenne Afrika, ahol magas a termékenység, és a fölös népesség szívesen jön Európába. A képzettséggel viszont baj van. Néhány évtizedes távlatban azonban ezen javítani lehetne, ha a fejlett országok célirányosan - egyfajta Afrika-politika keretében jelentős beruházásokat tennének az afrikai oktatási rendszerbe, illetve segítenék gazdaságukat növekedni úgy, hogy Kína helyett oda telepítik az iparukat. (Kína lassan már nem szorul rá a tőkeimportra, s ő maga is egyre inkább afrikai tőkeexportőr lesz, tehát fennáll a veszély, hogy még ezt a lehetőséget is Kína veszi észre elöttünk.)

Mindezek a lehetőségek azonban nem közvetlenül a TB átalakítását érintik, s így általában kevés szó esik róluk, illetve általában nem a TB kapcsán. A következő megoldás, illetve annak variációi viszont teljes egészében a TB-n belüli, illetve közvetlenül annak logikáját érinti, ugyanakkor itt sem célszerủ megspórolni a tágabb kitekintést, hiszen a környezet befolyásolja a pénzügyi megoldásokat is, sőt időnként (részleges) alternatívát is biztosít ezeknek. De mielőtt erre rátérnénk, tegyünk egy kitérőt a TB finanszírozásának és a longevity problémának az összefüggéséről.

\section{A TB FINANSZÍROZÁSA ÉS A LONGEVITY PROBLÉMA ÖSSZEFÜGGÉSE}

A fentiekben tehát arra a következtetésre jutottunk, hogy a TB finanszírozásában a meghosszabbodó élettartam által okozott nehézséget jól lehet kezelni a nyugdíjkorhatár indexálásával. A még mindig megmaradó problémát (amire végső soron az alább tárgyalandó részleges feltőkésitést javasoltuk gyógyírnak) pedig inkább az így átdefiniált (tehát csökkenő létszámú „relatív”) idősek arányának a feldúsulása okozza, ami viszont az alacsony fertilitási rátának köszönhető. Mondhatni az „ageing” néven ismert jelenség két tényezője közül a második, s ha elfogadjuk a fenti érvelésemet, akkor valójában az egyetlen. Meg kell azonban jegyezni, hogy a TB finanszírozása, illetve általában a TB működése nem egyszerűen „elszenvedi” a várható élettartam növekedését, hanem hozzá is járul ahhoz. Egy - nem utolsósorban a jó finanszírozás miatt - jól működő TB nyugdíj- és egészségbiztosítási rendszer ugyanis maga is megnöveli a 
nyugdíjasok várható hátralévő élettartamát, ami ezért így maga is hozzájárul saját longevity problémájához. Itt nem kerülhető meg, hogy rámutassunk arra, hogy a TB költséghatékonysága (legalábbis időskorban) kétféleképpen mérhető, s a kettő ellentmondásban van egymással. A TB célja felől vett egyfajta ,jóléti” hatékonyságot nagyjából úgy mérhetjük, hogy mennyi pénzbe kerül egy év jó egészségben vagy legalábbis szenvedés nélkül eltöltött nyugdíjas év. Ha a határráfordítás nem nő, akkor minél jobban nő a várható hátralévő élettartam, annál nagyobb ez a jóléti hatékonyság. De a TB költséghatékonyságát úgy is nézhetjük, hogy egyáltalán a GDP hány százalékába kerül (legyen, mondjuk „finanszírozási” hatékonyság), és minél inkább nő a várható hátralévő élettartam, ez annál nagyobb szám lesz. Mivel a TB „jóléti” hatékonysága ezt növeli, ezért csökkenti a TB „finanszírozási” hatékonyságát. Vagyis majdhogynem az a helyzet, hogy a „jólétileg” (vagyis lényegében: köznapilag) nem hatékony TB segítheti a TB finanszírozási hatékonyságát, vagyis az utóbbi értelemben a köznapilag rossz TB a jó. Például a rossz egészségügy kétszeresen is olcsó: azért rossz, mert keveset költenek rá, s mivel keveset költenek rá, ezért sok betegségbe halnak bele a betegek, s ez megintcsak olcsóvá teszi azt, hiszen őket már nem kell tovább kezelni. De hallottam olyan nyugdíjalapkezelőket is, akik azzal dicsekedtek, hogy akiknek ők nyújtanak nyugdíjat, azok sokkal tovább élnek, mint akik csak pici állami nyugdíjat kapnak. ${ }^{9}$

Feltehető ugyanakkor, hogy ez a hatás annál kisebb, minél magasabb szintről javul a nyugdíj-, illetve egészségügyi ellátás. Vagyis alacsony korábbi szintről való kis javulásnak is nagy élettartam-hatása lehet, de magas szintről indulva ez a hatás már - feltehetőleg elhanyagolható. (Feltehetőleg ezért sem beszélnek róla, hiszen a nyugdíjrendszerre nézve szégyenletesnek tekinthető, ha az olyan alacsony nyugdíjat nyújt, hogy jelentős mértékü ez a hatás. Ugyanakkor közepes szintű ellátásnál ez már valószínűleg mérhető nagyságú.)

\section{A NYUGDÍJ FINANSZÍROZÁSA - FELTÖKÉSÍTÉSI LEHETÖSÉGEK}

A fentiekben tehát arra jutottunk, hogy a TFR nagyobb mértékü csökkenése miatt előálló problémákat leginkább a tiszta PAYG rendszer részleges, megfelelő mértékű feltőkésítésével lehet kezelni. (lásd pl. Sinn [2001]) Ez, mint fentebb láttuk, arról az oldalról is enyhíti a problémát, hogy az előtakarékosság lejjebb viszi az aktívkori fogyasztási referenciapontot, amit a nyugdíjjal időskorban meg kell célozni. A választott megoldástól függően elképzelhető, hogy ebbe a feltőkésítésbe „eldugjuk” az egészségügy finanszírozásának részleges feltőkésítését is. Ugyanakkor itt legalább két problémába ütközünk:

1.Nem igazán tudjuk, hogy mekkora TFR-hiányra kalibráljuk a rendszert, mert nehéz megjósolni, hogyan is alakul a termékenység a jövőben. Az lenne a jó, ha a rendszer automatikusan illeszkedne a tényleges TFR-hez, vagyis növekedne az elötakarékosság, ha az lefele, és csökkenne, ha felfele mozdul, de nem világos, hogy egy ilyen automatizmust hogyan lehet beleépíteni a rendszerbe. ${ }^{10}$

2. Minél kisebb a TFR, annál nagyobb a szükséges elötakarékosság. Ha ezt a 20 éve a
Világbank által javasolt módon (World Bank [1994]) próbáljuk meg megoldani, vagyis mindenkit előtakarékosságra késztetünk, akkor tovább nyílik az az olló, ami már most is látható a gyermekesek és a gyermektelenek között. A gyermekesek a gyermekeket részben munkaidejük terhére nevelik, ami elveszi tőlük a megtakarítandó pénzük egy részét, illetve a nyugdíjjogosultságuk egy részét is. Ha növeljük az előtakarékosságot, akkor azt a gyermektelenek könnyen tudják teljesíteni, a gyermekesek pedig egyre nehezebben, vagyis arra ösztönözzük őket, hogy nekik se legyen gyermekük. Ezzel viszont ismét növeljük az elötakarékosság szükségességét, és még nehezebb helyzetbe hozzuk a még így is gyermeket nevelőket. Miközben a rendszer végső soron a felnevelt gyermekek járulékfizetésétől függ, vagyis egyre inkább megkérdőjelezhető a méltányossága.

Ha elemezzük ezt a problémát, akkor azt találjuk, hogy a folyó finanszírozású nyugdíjrendszer Samuelson által adott (Samuelson [1958]) filozófiája, amit én AI (aktívinaktív - utalással a Samuelson által figyelembe vett két életszakaszra) történetnek neveztem el (Banyár [2014a]) hibás, amit fel kell váltani egy új filozófiával (IAI - inaktív-aktív-inaktív történet). Ez a nyugdíjat a gyermeknevelési erőfeszítés (=emberi tőke beruházása) eredményének, vagyis tőkehozamnak tekinti, a járulékfizetést pedig ezen beruházás visszafizetésének. Emiatt a járulékokból azok és olyan arányban kell, hogy részesüljenek nyugdíjént, amilyen arányban hozzájárultak ehhez a beruházáshoz. Akik nem, azok pedig tegyék félre azt a pénzt, amit a gyermeknevelésen megtakarítottak, és nekik ebből lesz (elsősorban) nyugdíjuk. Vagyis a mai tisztán PAYG rendszer helyére egy vegyes, részben és szelektíven feltőkésített rendszert kell állítani, ami más megközelítésben teljesen feltőkésített, de az érintettek a tőke két fajtája között választhatnak: az emberi és a „fizikai” tőke között. Az előbbit a gyermekneveléssel választiák. Egy ilyen rendszer mindkét fenti problémát kezeli, hiszen automatikusan idomul a rendszer („,fizikai”) feltőkésítettsége a TFR-hez, s nem méltánytalan a gyermeket nevelőkkel szemben. ${ }^{11}$

\section{TOVÁBBI PROBLÉMÁK: MUNKAERÖPIACI HELYZET, NÉPESSÉG} INHOMOGENITÁSA

A nyugdíjkorhatár-indexálás megvalósításának van két implicit előfeltétele: 1.az időseket tudják foglalkoztatni, vagyis a munkaerőpiaci helyzet jó

2.a népesség a várható hátralévő élettartam szempontjából nem esik szét két (esetleg több) nagyon különböző alnépességre, vagyis homogén.

A munkaerőpiaci helyzetnek valójában általában kell jónak lenni, vagyis olyannak, hogy aki keres, az talál is munkát. Ha általában munkahelyhiány van, akkor az, hogy az idősek vagy a fiatalok foglalkoztatását csökkentik-e, az adott ország munkaerőpiaci szabályozásától, illetve általában a politikai szándékoktól függ. Ha - a szakszervezetek korábbi aktivitásának hatására - sok az alkalmazottakat védő szabály, akkor nehéz elbocsátani azt, akinek már van munkája, s emiatt nem is nagyon vesznek fel újakat. Összességében ez (mint pl. Franciaországban, ${ }^{12}$ vagy különösen Spanyolországban) abban csapódik le, hogy a fiatalkori munkanélküliség lesz nagy, nem az időskori. Ha ilyen szabályok nincsenek, akkor pedig 
inkább fiatalokat alkalmaznak, az időseket leváltják a munkahelyeken. Azt pedig, hogy általában jó lesz-e a munkaerőpiaci helyzet a jövőben, nem lehet tudni. Sokan félnek az automatizálás hatásától, mások úgy gondolják, hogy annyi jellegében új munkahely fog születni, mint amennyi régi emiatt megszünik. Lehetséges azonban, hogy tényleg kevesebb munkaerőre lesz szükség, s akkor a dolgozat elején említett megoldás, miszerint osszuk el az életpályán hosszabb időre az életpálya munkaidőt, különösen észszerű megoldás lesz.

Itt is felmerül azonban egy lehetséges inhomogenitási probléma, nevezetesen az, hogy az új munkahelyek csak a már amúgy is jól foglalkoztatott, magas képzettségű rétegeknek keletkeznek, $s$ a népesség egy jelentős része fokozatosan kiszorul a munkaerőpiacról. Ez közvetlenül nem a nyugdíjrendszer problémája lesz, hiszen akkor ők nyugdíjat sem fognak kapni, de lesz helyette egy sokkal általánosabb probléma - amivel persze itt most nem foglalkozunk, csak jelezzük.

Ha a népesség a várható hátralévő élettartam szempontjából szétesik két alnépességre, egy alacsony és egy magas várható hátralévő élettartamúra, akkor a korhatár fokozatos és általános emelése méltánytalan lehet a rosszabb várható élettartamú alnépességgel szemben. Igaz, ez a probléma csak akkor effektív, ha ezek a rétegek egyáltalán dolgozni tudnak, s így nyugdíjjogosultak lesznek. Ha a munkaerőpiaci és a várható élettartambeli inhomogenitás összefonódik - ami logikus lehet -, akkor ez a probléma egyre kevésbé a nyugdíjrendszerben jelentkezik.

\section{NYUGDÍJREFORM, GYERMEKEK ÉS A MAGYAR VERSENYKÉPESSÉG}

A magyar állami nyugdíjrendszer reformja nemcsak az érintettek (ellátottak és járulékfizetők) szempontjából fontos, hanem egyben a magyar versenyképesség fontos tényezője is. Az itt javasolt folyamatos korhatár-indexálás ennek a reformnak fontos tényezője lehet, de nem a legfontosabb. A legfontosabb a nyugdíj és a gyermeknevelés összekapcsolása lenne, ahogy azt már több írásomban (pl. Banyár [2014a], [2016] és [2019b]) is javasoltam. Ennek révén a magyar állami nyugdíjrendszerben - az állami nyugdíjrendszerek közül egyedül - megteremtenénk az eszköz-forrás illeszkedést (vagyis, hogy - szemben a mai rendszerrel - automatikus legyen a nyugdíjrendszer lehetőségeinek - eszköz - és ígéreteinek - forrás - összhangja), (Banyár [2019a]), s ezáltal hosszú távon fenntartható pályára tennénk azt. Elfelejtenénk a folyó finanszírozást, és egy szilárd, humántőke-alapú, feltőkésített nyugdíjrendszerré változtatnánk a jelenlegi rendszert, ami egyben biztosítaná azt is, hogy a gyermeknevelés az érintettek számára „jó üzletté” váljon, s ne maradjon áldozat, mint most. Vagyis ez a reform nemcsak a nyugdíjat, hanem a gyermekbe történő beruházást is új alapokra helyezné, biztosítva, hogy az is önfinanszírozóvá váljon. Ezáltal valósulhatna meg igazán az a politika által kitűzött helyes cél, hogy a gyermeket nevelők éljenek jobban, mint a gyermeket nem nevelők.

\section{HIVATKOZÁSOK}

'Az utóbbi néhány évben némely fejlett országban lassult, illetve stagnált a javulás üteme (Horváth [2019]). Az UN [2020] 15. oldalán lévő ábra is mutatja ezt a lassulást Európa és Észak-Amerika vonatkozásában, ugyanakkor az ezeknél jobb mortalitású Ausztralia ès $\mathrm{g}$-Zeland

'Egy friss, demográfiai jellegú cikk, már a címében is mutatja ennek a megközelitésnek az elterjedtségét: https://novekedes. a-65-ev-folottiek-aranya-magyarorszagon 'Egy nagyon hevenéészett gondolatmenet szerint a következő hüvelykujjszzabályt alkothatjuk. Képzeljük el, hogy mindenki rius népessèg esetén - az egész népesség létszáma egyenlő egy évfolyam népességszáma szorozva a születéskor várható élettartammal. Vagyis a hhoz, hogy fennmaradjon a stacionárius népesség, az egész népesség ennyied részének kell évente megszületnie. Tegyük most fel, hogy a várható hátralévő élettartam 0,1 évvel nő. Ez ugyanazt jelenti ebben a modellben, hogy a legidősebb kohorsz 10\%-a nem hal meg abban az évben, hanem csak a következőben. Tehát 10\%-kal kevesebb gyermek elég, hogy a letszam valtozatlan maradjon. Vagyis $0,1 \mathrm{ev}$ - folyamatosan fennmarado - varhato elettartam növekedés esetén a fertilitásnak - egyszeri alkalommal - elég a 2,1 90\%-annak, vagyis 1,89-nak lennie, 0,2 esetén pedig (ami közel van a mai magyar értékhez) 1,68 -nak. Persze ez így csak nagyon közelitő érték. A magyar népesség fogy, mert

a tényleges fertilitás még ennél is kisebb.
"Ld. Gulliver 3. utazása (többek között) a halhatatlan struldbrugok országába.

'Két életkorra, 0 és 60 évre számították ki az adatokat, amelyek elérhetớk nemenként és összzvontan is - itt most ez utóbbit használtam.

gy Augusztinovics Mária megállapította: „Az élettartam meghosszabbodásával ... nemcsak az öregség hosszabbodik meg, hanem minden életszakasz. A megnyert évek eloszlanak az életpályán. Kitolódik a munkaképes kor felső határa is, (8)

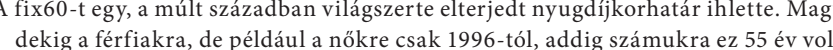
¿Valójában némileg bonyolultabb a dolog. Az előtakarékosság valóban csötkenti a jelenleg fogyasztásra fordíthatójövedelmet, igy azt a referencia életszínvonalat is, aminél nem akarunk idős korban rosszabbul élni. Ezzel viszont könnyebb is elérni ezt az új referencia életszínvonalat. Vagyis az előtakarékosság két oldalról is segíti megoldani a problémát.

${ }^{9} \mathrm{~A}$ dolog a német nyelvü Bécsben történt 2007-ben, ahol én mint magyar anyanyelvü elöadó angolul tartottam nyugdíj szemináriumot orosz anyanyelvủ hallgatóknak, akiknek - biztos-ami-biztos - azért egy ukrán anyanyelvủ hölgy tolmácsolt is. A hallgatóság zömét egy jakutföldi gyémántbánya nyugdíalapjának vezetỏi tették ki, sők dicsekedtek ily módon. Ami rávilágít arra is, hogy az orosz nyugdijrendszer akkoriban azért is kerülhetett viszonylag kevésbe, mert kvázi éhenhalasztotta a nyugdíjasokat.

${ }^{10} \mathrm{~A}$ World Bank [1994] ajánlása alapján megvalósult közép- és kelet-európai részleges feltőkésítést célzó nyugdijireformok, igy az 1998-as magyar is, nem tartalmazott ilyen automatizmust, nem is célozta meg, sa dizájnja eleve alkalmatlan is volt e követelmény teljesitésére. A magyar reform problémáiról lásd egyébként Banyár [2017]-t!

" jelenlegi ,samuelsoni” nyugdírendszerek elméleti problémáit én tártam fel a fent idézett tanulmányomban, de az ebből következő nyugdíjrendszer első megfogalmazását én magam először a Hyzl et. al. [2005] tanulmányban olvastam. Régi

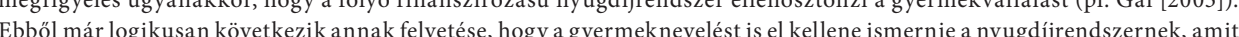
többen megtettek. Magyarországon például elsösorban a Botos házaspár népszerüsíti ezt az elképzelést ( $\mathrm{pl}$ B Botos- Botos [2020]) és sokan támadják is (lásd pl. Kovács (ed) [2012] tanulmányainak jelentős részét). Ugyanakkor ezek a felvetések két fontos (egymással összefügoö) elméleti tévedést tartalmaznak: 1. adottnak veszik a folyó finanszírozású nyugdírendszerek ,samuelsoni” designját, vagyis azt alapelvet, hogy a nyugdij a járulékfizetésért, azzal arányosan jár, ami hibás, 2 . úgy gondolják, hogy a gyermeknevelést azért kell a nyugdijrendszerben figyelembe venni, hogy ezzel is ösztönözzzük a gyermekvállalást (ami aztán majd megoldja a nyugdijrendszer problémáitit). Az egyébként kiváló Regös [2015] és Simonovits [2014] tanulmányok is ezekböl a feltevésekből indulnak k

"2Ezért van az az elsỏ látásra meghökkentỏ fejlemény, hogy Franciaországban a fiatalok idônként az alacsony nyugdijkorhatár mellett tuntetnek. Ez nem azèrt van, mert mar elore tudjak, hogy fiatalon akarnak nyugdijba menni, hanem mert nem látnak más módot arra, hogy alkalmazzák őket, mint azt, hogy az időseket elküldik nyugdíba, s helyettük őket veszik fel. 


\section{IRODALOMJEGYZÉK}

Augusztinovics Mária [2005]: Népesség, foglalkoztatottság, nyugdij, Közgazdasági Szemle, LII. évf., 2005. május (pp. 429-447.)

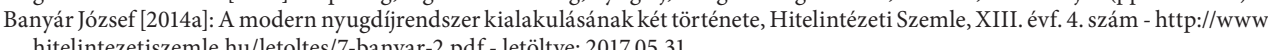

Banyár József (2014b): Consequences of cross-border human capital transfers on national PAYG systems, In.: European pension
system: Fantasy or reality, Report on the conference of the Central Administration of National Pension Insurance organised in cooperation with the International Social Security Association European Network held in Budapest, Hungary on 19th September 2014 Banyár, József [2016] Possible reforms of Pay-as-you-go pension systems, European Journal of Social Security, Vol 18, Issue 3, 2016 - http://journals.sagepub.com/doi/abs/1.3117/138826271601800303 - letöltve: 2017.05.31.

Berér

作 - letölttve: 2017.06.28.

Banyár Jozsef [2019a]: Ageing and the Pay-as-you-go (PAYG) Pension System's Asset-liability (Mis)Matching.

https://doi.org/10.24917/9788395373718.7 Letöltve 2020.10.08.
Ł. Tomczyk - A. Klimczuk (Eds.), Between Successful and Unsuccessful Ageing: Selected Aspects and Contexts (163-206). Kraków: Uniwersytet Pedagogiczny w Krakowie.

Banyár József [2019b]: Az állami nyugdijrendszer „születési” hibaii és javitásának fö iránya, Pénzügyi Szemle 2019/4. (pp. 540-553.)

- htttps://doi.org/10.35551/PSZ_2019_4_4 Letöltve 2020.10.8
Botos Katalin - Botos József (2020): Nyugudijirendzzer a váttozó társadalomban, Pénzügyi Szemle 2020/1. (pp. 7-22.) - https://doi. org/10.35551/PSZ_2020_1_l, angolul: Pension System in the Changer loombergBusinessweek [2016]: Mexico's Richest Man Wants a Three-Day Workweek. Bloomberg Businessweek, augusztus 8. CLOVIS INSTITUTE [2018]: Muslim Fertility in Europe, MARCH 26, 2018 - http://clovisinstitute.org/muslim-fertility-in-europe/ Letöltve: 2020.10 .08$.

[2012]: FEHER KÖNYV - A megfelelő, biztonságos és fenntartható európai nyugdijak menetrendje - http://ec.europa.eu/social/ (

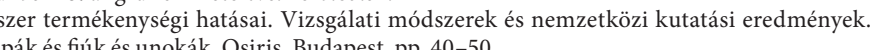
Horváth Gyula 2019]: Fordulat a halandósagban - Biztosittásés kockázat VI. évf3. szám pp. 18-33.o. - https://mabisz.hu/wp-content/ uploads/2019/10/6iztositas-es-kockazat-6-evf-3-szam-2-cikk.pdf

Hot. -

Sustainable Pension Solutions (Innovative approach), Skoda Auto College, (20r/slozka.pl?:id=1676;download=1924 - letöltve: 2017.06.28.

Kovács Erzsébet (szerk.) (2012): Nyugdijés gyermekvállalás tanulmánykötet - 2012, Gondolat

Madár István [2017]: Nem az a veszély, hogy elfogynak a nyugdijak, hanem hogy másra nem jut pénz - interjú Holtzer Péterrel, index.hu, 2017.03.06. - http://www.portfolio.hu/gazdasag/nyugdijrendszer/nem_az_a_veszely_hogy_elfogynak_a_nyugdijak_

Regős Gábor (2015): Can Fertility be Increased With a Pension Reform? Ageing International, June 2015, Volume 40, Issue 2, pp how - majus 18-i szämban. Elérhetóek: http://www.economist.com/news/leaders/21721371-death-inevitable-bad-death-notbeyond-fighting-death -esing it-better + http://wwweconomistcom/news/letters/21722151-dying puerto-rico-jang-moveand-more-letters-editor - Letölttve: 2017.05.31. Samuelson, Paul A. [1958]: An Fxact Consumption-

of Political Economy, Vol. 66, No. 6 (Dec., 1958), pp. 467-e of Interest with or without the Social Contrivance of Money, Journal https://doi.org/10.1086/258100 Letöltve 2020.10.08.

Simonovits András [2014]: Gyermektámogatás, nyugdij és endogén/heterogén termékenység - egy modell. Közgazdasági Szemle, to a funded system. ifo Studien 47, pp. 77-94.
UN [2015]: World fertility patterns 2015 - http://www.un.org/en/development/desa/population/publications/pdf/fertility/world-

fertility-patterns-2015.pdf Letöltve 2020.10.08.
UN [2020]: World Mortality Report 2019 - https://www.un.org/en/development/desa/population/publications/pdf/mortality/ W

ford Univeristy Press, 1994 - http://documents.worldbank.org/

curated/en/973571468174557899/pdf/multi-page.pdf - letöltve: 2017.05.31. 